\title{
Characterization of bioflocculants produced by bacteria isolated from crude petroleum oil
}

\author{
${ }^{1}$ S. Zaki; ${ }^{1}$ S. Farag; ${ }^{1}$ G. Abu Elreesh; ${ }^{2}$ M. Elkady; ${ }^{1}$ M. Nosier; ${ }^{1}{ }^{*} D$. Abd El Haleem \\ 'Department of Environmental Biotechnology, Genetic Engineering and Biotechnology Research Institute, City for \\ Scientific Research and Technology Applications, Burgelarab, Alexandria, Egypt \\ ${ }^{2}$ Department of Fabrication Technology, Advanced Technology and New Materials Research Institute, City for \\ Scientific Research and Technology Applications, Alexandria, Egypt
}

Received 21 October 2010; revised 25 April 2011; accepted 9 August 2011

\begin{abstract}
The aim of this study was to look for high efficient bioflocculant-producing microorganisms. Among 36 bacterial colonies isolated from a crude petroleum oil sample, three of them as Bacillus subtilis and Pseudomonas spp. exhibited flocculation activity exceeding $90 \%$ after 3 days of cultivation. They were identified by $16 \mathrm{~S}$ rDNA sequence analysis as Bacillus subtilis and Pseudomonas sp. Spectroscopic analysis of the polymers by nuclear magnetic resonance and fourier-transform infrared revealed that the polymers were glycoproteins. These polymers were soluble in water and insoluble in any organic solvents tested. The effects of bioflocculant dosage, temperature and $\mathrm{pH}$ on the flocculation activity were evaluated. The maximum bioflocculation activities were observed at an optimum bioflocculant dosage of $3.5 \mathrm{mg} / \mathrm{L}$ (strains Bacillus subtilis and Pseudomonas) and $5.0 \mathrm{mg} / \mathrm{L}$ (strain CPO14), respectively. In addition, these biopolymers were able to flocculate kaolin suspension $(5 \mathrm{~g} / \mathrm{L})$ over a wide range of $\mathrm{pH}(\mathrm{pH} 3-9)$ and temperature $\left(5-50^{\circ} \mathrm{C}\right)$ tested in the presence of $\mathrm{CaCl}_{2}$. The highest flocculation activities of strains $\mathrm{CPO}, \mathrm{CPO} 13$ and $\mathrm{CPO} 14$ were $96.03 \%, 92.17 \%$ and $97.59 \%$, respectively in the early stationary phase (at $24 \mathrm{~h}$ ), while the cell production reached its maximum in the stationary phase (at $72 \mathrm{~h}$ ). Their efficient flocculation capabilities suggest potential applications in industries.
\end{abstract}

Keywords: Bioflocculant; Biopolymer; Flocculation activity; Optimization

\section{INTRODUCTION}

Industrial process is a potential source of pollution and requires a specific treatment for the waste produced. Introduction of waste treatment increases the plant cost, therefore an attempt to improve its efficiency is valuable. This applies to all kinds of industries but is particularly important for low or medium added value industries with difficult wastes like tanneries and clay processing industry. Flocculation is the most widely used process for treating the wastewater in these kinds of industries (Rossini et al., 1999). Separation by flocculation is effective and sufficient when the end objective is reduction in sludge volume and rapid separation of solids from liquids (Besra et al., 2003).

The problem of removal of kaolinite turbidity from the effluents before discharging into the environment was studied by many researchers. Faust and Aly (1983)

*Corresponding Author Email: abdelhaleemm@yahoo.de Tel.: +2011586 6113; Fax: +2034593420 quote extensive application of kaolinite suspensions as a model for natural turbidity of raw surface water in Jar Test studies of coagulation and flocculation in the laboratory. Inorganic coagulants such as alum in combination with lime have been conventionally used for the removal of clay particles in the effluents from clay processing industry as well as from raw water. The sludge formed from such treatment poses disposal problems because of its aluminium content and tend to accumulate in the environment (Faust and Aly, 1983). Stauber et al. (1999) and Divakaran and Sivasankara, (2001) have reported that although not conclusively proved, increasing concern about the residual aluminium, which may be present in water as a result of alum treatment, is being expressed by the public in connection with Alzheimer's disease. Thus, it has become necessary to develop harmless, more efficient and environment friendly flocculants for removal of turbidity in surface waters and effluents. 
Bioflocculants have received considerable scientific and biotechnological attention in recent years due to their biodegradability, benign nature and lack of secondary pollution of their degradative intermediates (Salehizadeh and Shojaosadati, 2001). They reported that bioflocculants are microorganism-produced special natural organic macromolecule substances that can flocculate suspended solids, cells, colloidal solids, etc. In recent years, several kinds of microorganisms, which secrets flocculation biopolymer, have been screened and isolated from activated sludge, soil and wastewater. The species include bacteria, fungi, actinomyces and algae. Generally, soil and activated sludge samples are the major sources for isolating bioflocculant-producing microorganisms (Abd-El-Haleem et al., 2008). However, isolation and characterization of bioflocculant-producing microorganisms from crude petroleum oil samples were not well documented in literatures. Therefore, present study aims to look for bioflocculant-producing microorganisms in crude petroleum oil sample collected on 28 May 2009 from a sews-gulf oil drilling field in Egypt. Screening, isolation and characterizations of both bioflocculant-producing microorganisms and their extracellular bioflocculants were performed.

\section{MATERIALS AND METHODS}

Media and cultivation conditions Isolation medium

The Sup- plemented nutrient broth (SNB) medium used to isolate bacteria from the oil sample (collected from a sews-gulf oil drilling field in Egypt) was containing per liter of $500 \mathrm{~mL}$ of Nutrient Broth and 500 $\mathrm{mL}$ mineral salt solution. The $500 \mathrm{~mL}$ of salt solution was prepared by adding the various salts such as $\mathrm{KH}_{2} \mathrm{PO}_{4}, 20 \mathrm{~g} ; \mathrm{K}_{2} \mathrm{HPO}_{4}, 5.0 \mathrm{~g},\left(\mathrm{NH}_{4}\right)_{2} \mathrm{SO}_{4}, 30 \mathrm{~g} ; \mathrm{NaCl}$, $0.1 \mathrm{~g} ; \mathrm{FeSO}_{4} .7 \mathrm{H}_{2} \mathrm{O}, 0.01 \mathrm{~g} ; \mathrm{MgSO}_{4} .7 \mathrm{H}_{2} \mathrm{O}, 0.2 \mathrm{~g}$; $\mathrm{CaCl}_{2} \cdot 2 \mathrm{H}_{2} \mathrm{O}, 0.01 \mathrm{~g} ; \mathrm{MnSO}_{4} \cdot 7 \mathrm{H}_{2} \mathrm{O}, 0.2 \mathrm{~g} ; \mathrm{CaCl}_{2} \cdot 2 \mathrm{H}_{2} \mathrm{O}$, $0.01 \mathrm{~g}$; and $\mathrm{MnSO}_{4} \cdot \mathrm{H}_{2} \mathrm{O}, 0.002 \mathrm{~g}$, glucose, $0.03 \%(\mathrm{w} / \mathrm{v})$; and yeast extract, $0.03 \%(\mathrm{w} / \mathrm{v})$ (Francy et al., 1991). One-half SNB medium with $2 \%$ Bacto Agar (SNA) was used to isolate heterotrophs.

\section{Prescreening medium}

The prescreening medium used to select for bioflocculant-producing bacteria contained (per liter) $1 \%$ glucose, $0.35 \%$ yeast extract, $0.5 \% \mathrm{~K}_{2} \mathrm{HPO}_{4}, 0.2 \%$ $\mathrm{KH}_{2} \mathrm{PO}_{4}, 0.05 \% \mathrm{MgSO}_{4} 7 \mathrm{H}_{2} \mathrm{O}, 0.01 \% \mathrm{NaCl}$ and agar 1.5 $\%$. The broth of the prescreening medium was used as a seeding medium.

\section{Fermentation medium}

The fermentation medium was containing per liter; glucose $10 \mathrm{~g}, \mathrm{NH}_{4} \mathrm{Cl} 7 \mathrm{~g}, \mathrm{~K}_{2} \mathrm{HPO}_{4} 0.5 \mathrm{~g}, \mathrm{MgSO}_{4} 0.5 \mathrm{~g}$, $\mathrm{FeCl}_{3} 40 \mathrm{mg}, \mathrm{CaCl}_{2} 150 \mathrm{mg}$ and $\mathrm{MnSO}_{4} 140 \mathrm{mg}$.

\section{Cultivation conditions}

The initial $\mathrm{pH}$ of all media was adjusted to 7.2 to 7.5 with $\mathrm{NaOH}(1 \mathrm{M})$ and $\mathrm{HCl}(0.5 \mathrm{M})$. All the media were prepared with distilled water and sterilized at $121^{\circ} \mathrm{C}$ for 20 min. All cultivations were done at $30^{\circ} \mathrm{C}$.

Isolation, screening and identification of bioflocculant-producing bacteria

Screening process for bioflocculant-producing bacteria was performed in two experimental steps. First, all bacteria that might exist in the sample were isolated by adding $1 \mathrm{~mL}$ of oil sample to $99 \mathrm{~mL}$ of SNB medium in $250 \mathrm{~mL}$ flasks. The mixture was placed on a rotary shaker at $200 \mathrm{rpm}$ for $2 \mathrm{~h}$ at $30^{\circ} \mathrm{C}$ to produce a welldispersed suspension. Subsequently, the suspension was diluted serially in SNB broth and plated in triplicate on one-half SNB with 2\% Bacto Agar to isolate heterotrophs. The plates were incubated at $30^{\circ} \mathrm{C}$. Pure cultures of bacteria were isolated by cycles of re-plating on SNB agar plates. Thirty six pure bacteria with different colony morphologies were isolated and maintained on Nutrient Agar slants until used.

Secondly, to screen among all isolates for bioflocculant-producing bacteria, a loop of each isolate was suspended in sterile $1 \mathrm{~mL}$ distilled water and an aliquot $\sim 100 \mu \mathrm{L}$ was spread on the prescreening medium and incubated at $30^{\circ} \mathrm{C}$ for $48 \mathrm{~h}$ (Dermlim et al., 1999, Abd-El-Haleem et al., 2008). Microorganisms were screened for their abilities to produce bioflocculant based on colony morphology (mucoid and ropy) (Murray et al., 1994). The positive strains were grown in $50 \mathrm{~mL}$ fermentation medium in $250 \mathrm{~mL}$ flasks on a rotary shaker at $30{ }^{\circ} \mathrm{C}$ for 3 days. At the end of cultivation, the culture broths were measured for flocculation activities (described below).

The strains with the highest flocculating activities (CPO8, CPO13 and CPO14) were selected and identified based on $16 \mathrm{~S}$ rDNA sequencing. Their isolated genomic DNA was subjected to PCR amplification of $16 \mathrm{~S}$ rDNA using universal primers. Amplified products were gel purified using Qiagen gel extraction kit and purified products were sequenced (Kim et al., 2006). Subsequently, comparative sequence analysis of $16 \mathrm{~S}$ 
rDNA amplified genes was performed and a phylogenetic tree was generated according to the procedure described previously by Al-Thani et al. (2009).

\section{Determination of flocculation activity}

Flocculation activities were calculated and measured using a modified Kaolin clay suspension method (Kurane et al., 1986). A mixture of $5 \mathrm{~g} / \mathrm{L}$ synthetic clay suspension (Sigma-Aldrich, 0.1-4 $\mu \mathrm{m}$ particle size) with $0.5 \mathrm{~mL}$ bioflocculant solution (culture broth, cell-free supernatant or extracted biopolymer) in the presence of $\mathrm{CaCl}_{2}$ (as coagulant) was stirred with rapid mixing at 230 $\mathrm{rpm}$ for $2 \mathrm{~min}$, followed by slow mixing at $80 \mathrm{rpm}$ for 3 min using Laboratory Flocculator (Jar Tester Model CZ150) and left standing for $5 \mathrm{~min}$. A sample for Optical densities (OD) measurement was withdrawn using automatic pipette from a height of $3 \mathrm{~cm}$ below the surface of clay suspension. Relying on the upper phase OD for clay suspension that was measured at $550 \mathrm{~nm}$ with a spectrophotometer (7230G, Shanghai, China) the flocculation efficiency of the different isolated strains was screened. A control was prepared using the same method but the sample was replaced by distilled water. The flocculation activity was calculated according to the equation:

Flocculationactivity $(\%)=\left[\frac{A-B}{A}\right] \times 100$

Where A and B are the supernatant OD of the control (clay suspension without any bioflocculant addition) and sample respectively, at $550 \mathrm{~nm}$.

\section{Time course of bioflocculant production}

Time courses of the selected strains were carried out by cultivating in fermentation medium with the addition of $5 \%$ seeding culture ( $24 \mathrm{~h}$ and viable cell count of $10^{8}$ $\mathrm{CFU} / \mathrm{mL}$ ) at $30^{\circ} \mathrm{C}$ on a rotary shaker at $200 \mathrm{rpm}$ for 7 days. Samples were taken every $12 \mathrm{~h}$ to measure, optical density (OD $600 \mathrm{~nm}$ ) and flocculation activity (as described above).

\section{Partial purification of the bioflocculants}

To produce bioflocculants, the strains were precultured in the seed medium as described above and inoculated into fermentation medium with the addition of $2 \%$ starter culture $(24 \mathrm{~h})$ on a rotary shaker $(200 \mathrm{rpm})$ at $30{ }^{\circ} \mathrm{C}$ for another $24 \mathrm{~h}$. To partially purify bioflocculants, culture broths were centrifuged to remove cells by centrifugal separation $(4000 \mathrm{~g}, 30 \mathrm{~min})$.
Subsequently, cell-free supernatants were freezedried. The lyophilized precipitates were redissolved in an appropriate amount of distilled water then reprecipitated with four volumes of cold $95 \%$ ethanol and left for four hours at $4{ }^{\circ} \mathrm{C}$. After centrifugation at $7500 \mathrm{~g}, 4^{\circ} \mathrm{C}$ for $20 \mathrm{~min}$, above steps were repeated for two additional times and the final precipitates were freeze dried.

\section{Characterization of the partially purified biopolymers}

Infra-red spectra (IR) of the biopolymers were measured on a $\mathrm{KBr}$ disk with a Perkin-Elmer series 1600 FT-IR to determine the functional groups of the biopolymers. The ${ }^{1} \mathrm{H}$ NMR spectra of the bioflocculants were recorded on a $500 \mathrm{MHz}$ Bruker a JOEL GSX 500 spectrometer $(500 \mathrm{MHz})$. The bioflocculants were dissolved in $2 \mathrm{H}_{2} \mathrm{O}$. The protein concentrations of the biopolymers were determined according to Bradford method (Bradford, 1976). Total sugars were determined by the phenol-sulfuric acid reaction using the procedure of Chaplin and Kennedy (1994). Additional analysis of the biopolymers was performed, which included the solubility test in distilled water and several solvents such as acetone, carbon tetrachloride, ethanol, isopropanol, hexane, methanol and nitrobenzene (Collins et al., 1973). The effects of polymer concentrations (final concentration of $0-7 \mathrm{mg} / \mathrm{L}$ ) on the flocculation activity were studied. Subsequently, the effects of $\mathrm{pH}(3-12)$ and temperature $\left(5-100^{\circ} \mathrm{C}\right)$ on the flocculation activity of the partially purified biopolymers were studied by measuring the flocculation activity of the reaction mixture containing the optimum concentration of biopolymers at the specified ranges of $\mathrm{pH}$ and incubated at different temperatures (Kwon et al., 1996).

\section{RESULTS AND DISCUSSION}

Screening and identification of bioflocculantproducing bacteria

Despite, so many studies about bioflocculants have been done; flocculation activity and culture cost of bioflocculants are still the major limiting factors with regard to their application (Zhang et al., 2007). Consequently, there is a need to identify new microorganisms especially from unusual environments (e.g. crude oil) with high bioflocculantproducing ability and improve upon the flocculation efficiency of the known bioflocculants. It is known 
that crude oil or oil-contaminated sites are the main sources of biosurfactant-producing microorganisms (Yin et al., 2009). However, no previous report exists on the isolation and characterization of bioflocculantproducing microorganisms from crude petroleum oil. In the present study, a total of 36 colonies were isolated from crude petroleum oil sample, and 10 pure culture strains with slimy or mucoid appearance were screened on the basis of kaolin suspension flocculation activity over $85 \%$ (data not shown). Among them, three strains CPO8, CPO13 and CPO14 having kaolin at flocculation activity exceeding $90 \%$ were selected for further studies.

According to their $16 \mathrm{~S}$ rDNA sequence analysis strains CPO8 and CPO13 were belonging to the species of Bacillus subtilis. While, strain CPO14 was identified as Pseudomonas sp., respectively. Their $16 \mathrm{~S}$ rDNA sequences have been deposited in the GenBank database with accession numbers HQ015371, HQ015373 and HQ015374. Phylogenetic tree based on 16 S rDNA sequences was constructed using the neighbor-joining method (Fig.1). Out of these results, two among three selected bioflocculant-producing bacteria are belonging to the genus Bacillus. This result was in the same direction with many previous studies which reported that several bacterial strains closely related to the genus Bacillus able to produce bioflocculants (Shih et. al, 2001; Deng et al., 2003; Abd-El-Haleem et al., 2008; Xiong et al., 2010).

The effect of the time course on both growth and bioflocculants production of the three strains are given in Fig. $2 \mathrm{a}$ and 2b. The OD curve that may be represent the cell growth shows a sharp increment in the first 72 $\mathrm{h}$ then tends to be constant over the remaining studied culturing period. However, the flocculation activity during this period has been increased and reached its maximum value of $96.03 \%$ (COP8), $92.17 \%$ (CPO13) and $97.59 \%$ (CPO14), respectively at $24 \mathrm{~h}$, then decreased slightly until $132 \mathrm{~h}$. Concerning both the bioflocculant production and the cell growth profiles,

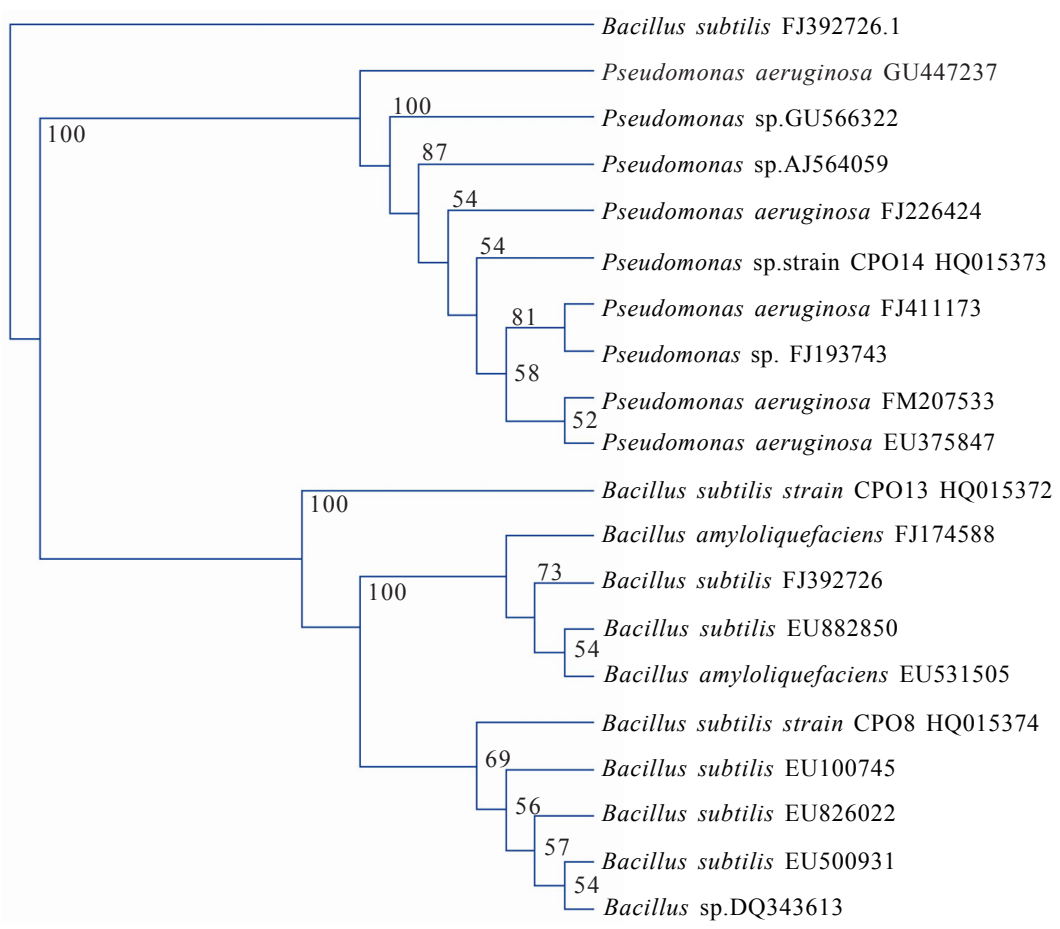

Fig. 1: Phylogenetic tree showing the relationships among the selected isolates (in boldface) and other closely related sequences collected from the Gene Bank. The dendrogram was generated by the neighbor-joining method. Bootstrap values per 100 bootstrap analysis presented for values greater than $52 \%$. The microorganism Bacillus subtilis FJ 392726 was used as an out-group 

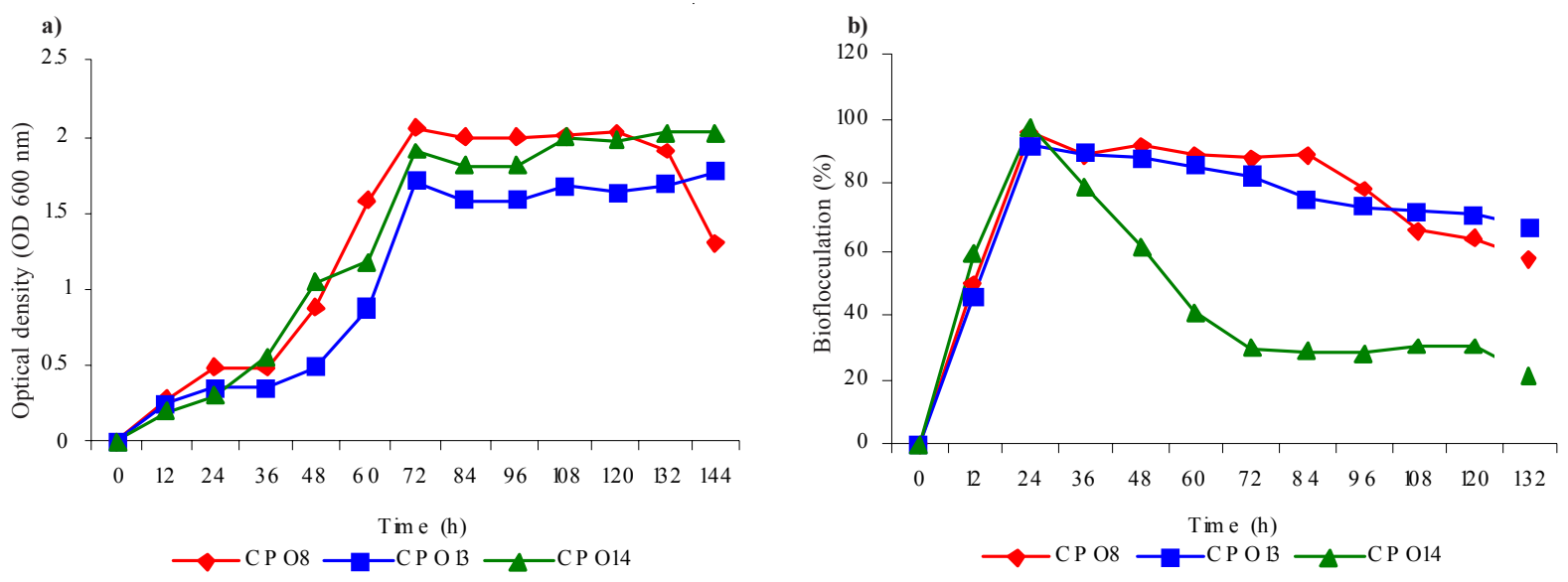

Fig. 2: Time course of growth (a) and bioflocculation activity (b) of strains CPO8, CPO13 and CPO14 in fermentation medium

it is evident that the bioflocculant production was almost in parallel with cell growth till $132 \mathrm{~h}$ studied (Liu et al., 2010). Where the produced bioflocculant reached its maximum flocculating efficiency in the early stationary phase (at $24 \mathrm{~h}$ ), while the cell production reached its maximum in the stationary phase (at $72 \mathrm{~h}$ ), indicating that the bioflocculant was produced by biosynthesis during its growth, not by cell autolysis (Lu et al., 2005). However, as the incubation time increased, the flocculating rate started to decrease in spite of the OD still recorded high values that may be related to the turbidity of the produced bioflocculant. This result indicated that all tested strains produce extracellular bioflocculants. Accordingly, in order to produce bioflocculant with high flocculating efficiency, $24 \mathrm{~h}$ culturing time has been chosen. Previously, the maximum flocculant production of Alcaligenes latus was achieved at the middle and late stage of the logarithmic growth phase (2-3 days), and flocculation activity began to decrease during the late stationary phase due to the activity of deflocculation enzymes (Kurane and Nohata, 1991). The growth curve of $P$. mirabilis TJ1 showed that the production of its bioflocculant was almost parallel with cell growth. The bioflocculant of P. mirabilis TJ1 reached its maximum flocculation rate $(93.13 \%)$ at stationary phase (Xia et al., 2008). In the same way, production of the bioflocculant by Enterobacter aerogenes was in parallel with cell growth and reached its maximum flocculation rate in early stationary phase (Lu et al., 2005). The flocculation rate of the bioflocculant from Serratia ficaria and Bacillus sp. F19 reached its maximum (94.3\% and $97 \%$, respectively) in early stationary phase (Gong et al., 2008).

\section{Characterization of bioflocculants}

The phenol-sulfuric acid method showed that the partially purified biopolymers contained $74 \%, 40 \%$ and $47 \%$ of total sugars, while protein contents detected by the Bradford method were $13 \%, 17 \%$ and $14 \%$ for the strains CPO8, CPO13, and CPO14, respectively, indicating the composition of all bioflocculants are glycoproteins. The Fourier-transform Infra-red (FTIR) spectra (Fig. 3 a, b and c) of the three bioflocculants were analyzed according to Xiong et al. (2010). It clearly showed the presence of carboxyl, hydroxyl, amide and amino groups in its molecules, which are the preferred groups for the flocculation, similar to those observed in polyelectrolytes (GaneshKumar et al., 2004). The spectra showed a broad stretching intense peak displayed around $3440 / \mathrm{cm}$ that was characteristic of hydroxyl and amino groups (Liu et al., 2009). The weak stretching band at $\sim 2955 / \mathrm{cm}$ known to be typical of carbohydrates, indicated $\mathrm{COH}$ asymmetrical stretching vibration. An asymmetrical stretching peak observed at $\sim 1,640 / \mathrm{cm}$ was characteristic of $\mathrm{CAO}$ stretching vibration in ONHCOCH3 (Xiong et al., 2010). The weak band near $1405 / \mathrm{cm}$ indicates the bending vibration of $\mathrm{CH}_{3}$ and the scissor vibration of $\mathrm{CH}_{2}$. The weak peak at 1,261/ $\mathrm{cm}$ in the bioflocculants produced by the Bacillus strains CPO8 and CPO13 may be assigned to be CAO symmetrical and asymmetrical stretching of a carboxylate group in the bioflocculant. However, this 
peak was absent in the bioflocculant produced by strain CPO14. In addition, the strong absorption band at the range of $1049-1097 / \mathrm{cm}$ indicated asymmetrical stretching vibration of a C-O-C ester linkage. These infrared spectra showed characteristic peaks for carbohydrates and amides. Therefore, it can be inferred that the bioflocculant is a types of glycoproteins.

To confirm FTIR results, Proton nuclear magnetic resonance ( $\left.{ }^{1} \mathrm{HNMR}\right)$ spectra analysis of the three bioflocculants were performed. As shown in Fig. 4 a, b and $\mathrm{c}$, the first notable result of the ${ }^{1} \mathrm{H}$ NMR spectra was that the spectra were virtually identical. In addition, the presence of carbohydrates is recognized by the intense signals in the characteristic bulk region at 3.4-
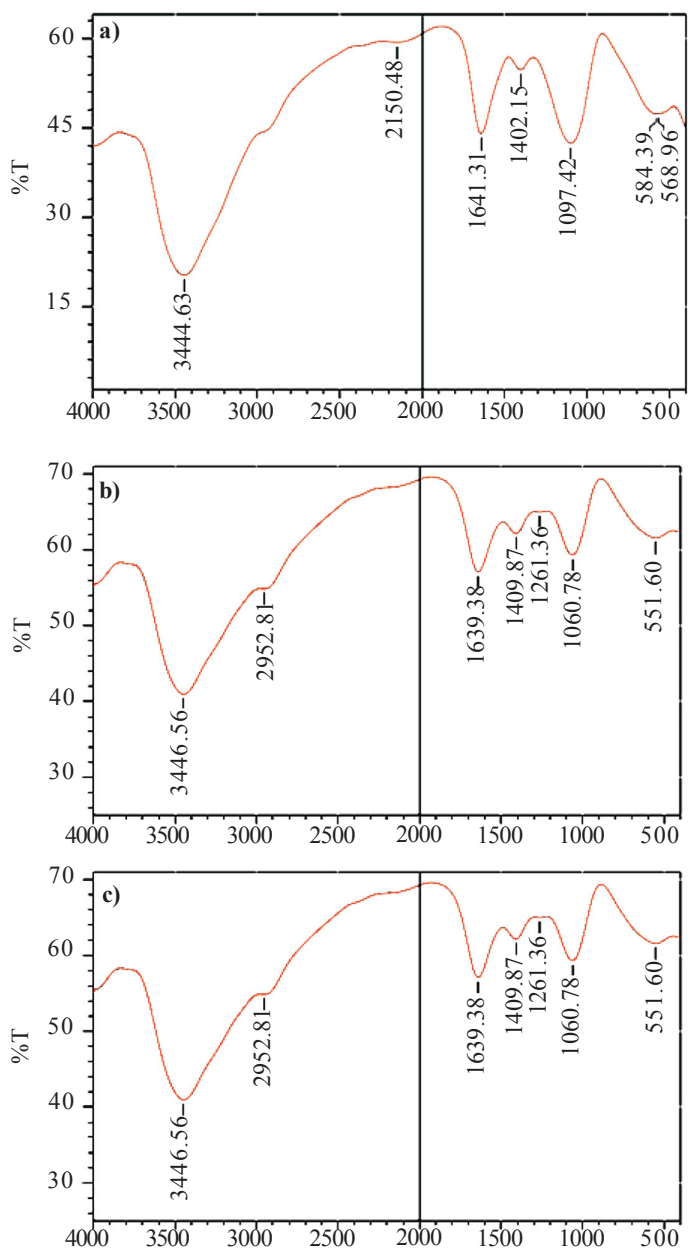

Fig. 3: FT-IR spectra of the partially purified biopolymers from strains CPO8 (a), CPO13 (b) and CPO14 (c)
$4.3 \mathrm{ppm}$. In the region 4.8-5.2 ppm severe overlap of the carbohydrate anomeric signals with those stemming from C-protons of the protein backbone is observed. Previously, de-Beer et al. (1994) reported that most cross peaks stemming from carbohydrates attached to an intact glycoprotein appear in a region (3.4-5.2 ppm) in the spectrum essentially devoid of cross peaks of the protein backbone. However, the strong water (HOD) signal at $4.8 \mathrm{ppm}$ obscures the beta-anomeric proton signal at about $4.75 \mathrm{ppm}$. The signals for the methyl protons of the 6-deoxy sugars are seen at about at 1.44-1.48 ppm (Kumar et al., 2004). The results obtained from the NMR analysis confirmed the FTIR results and indicated that all of selected bacterial strains produced
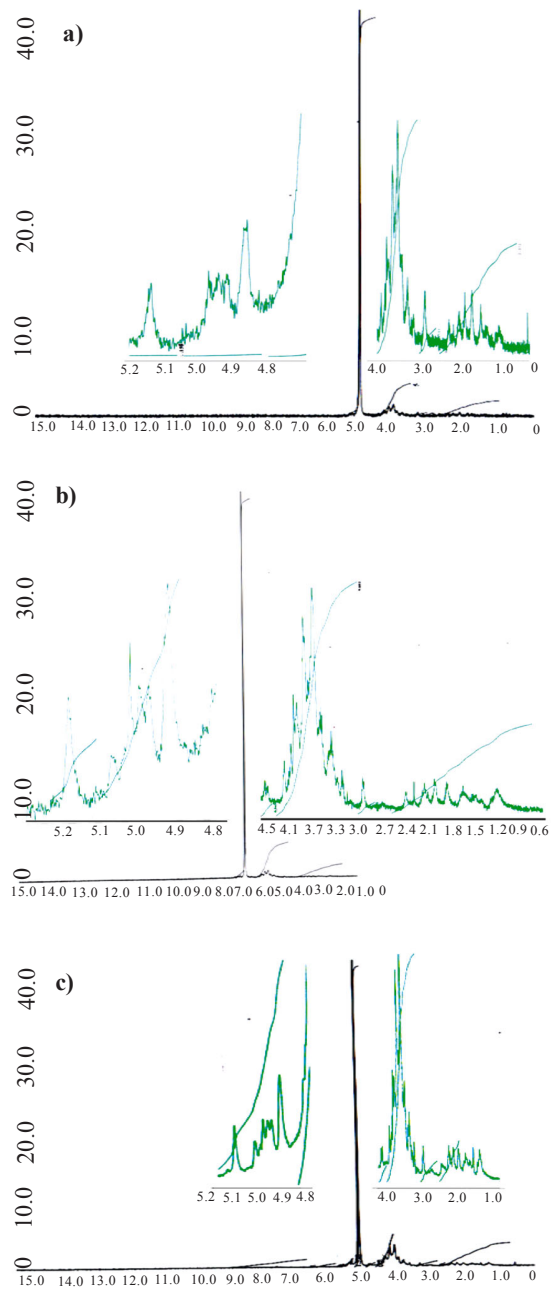

Fig. 4: ${ }^{1} \mathrm{H}$ NMR spectra of the partially purified polymers from strains CPO8 (a), CPO13 (b) and CPO14 (c) 
glycoproteins. Out of these results, the protein and the carbohydrate contents of the purified biopolymers may explain their stability toward all studied organic solvents (acetone, methanol, ethanol, chloroform, dimethylsulphoxide). However, it has a tendency to be soluble in water as well as both acidic and alkaline media.

\section{Effect of bioflocculants concentration $\mathrm{pH}$ and temperature on bioflocculation activity}

Fig. 5 shows the relationship between the flocculants dosages and flocculation activities. When the culture broth in kaolin suspension $(5.0 \mathrm{~g} / \mathrm{L})$ was tested in the dosage range of $0.5-39 \mathrm{mg} / \mathrm{L}$, it was apparent that the flocculation activity increased proportionally to the flocculant dosage of 0.5 to $7.0 \mathrm{mg} / \mathrm{L}$ and was highest at $3.5 \mathrm{mg} / \mathrm{L}$ of strains CPO 8 and CPO13 and at $5.0 \mathrm{mg} / \mathrm{L}$ of strain CPO14, respectively. These results could be clarified as follows: a) The incomplete dispersion of excess polysaccharide, only the kaolin particles around the polysaccharides participated in the flocculation reaction, therefore, other kaolin particles did not participate in the reaction (Yokoi et al., 1997) and b) The excess polysaccharide was oversaturated on many binding sites of the surface of kaolin particles, thus the attractive force of the other particles was reduced and the flocculation activity decreased (Kwon et al., 1996). Thus, either the deficiency or excess amount of polysaccharide and kaolin clay decreased or even prevented the flocculation activity (Lee et al., 1995).

The partially purified bioflocculants had the optimum $\mathrm{pH}$ for flocculation activity at $\mathrm{pH} 7$ and were not affected by the $\mathrm{pH}$ range of 3-9 (Fig. 6a). At higher $\mathrm{pH}$ of 9-11, the flocculation activity decreased gradually with all strains except of strain CPO13 which still has high flocculation activity $(96.4 \%)$ up to $\mathrm{pH} 11$. The $\mathrm{pH}$ range for flocculation reaction of these biopolymers were wider than those of the polyglutamate from Bacillus subtilis PY-90 (pH range of 3-5) (Yokoi et al., 1995 ) and the cationic polysaccharide from Paecilomyces sp. I-1 (pH range of 4-8) (Takagi and Kadowaki, 1985). It is demonstrated that the biopolymer solution is suitable to be applied in neutral, weakly acid and weakly alkaline circumstances. However, its flocculation efficiency slightly reduces at highly acidic $(\mathrm{pH}<5)$ and highly alkaline $(\mathrm{pH}>9)$ circumstances. This may be returned to the biopolymer shows different electric states at different $\mathrm{pH}$, in turn affects the bridging efficiency of the biopolymer for clay powder (Yong et al., 2009).

However, the flocculation activity of the bioflocculants produced by strains $\mathrm{CPO} 8$ and $\mathrm{CPO} 13$ was not affected by increasing the reaction temperatures in the range of $5-70^{\circ} \mathrm{C}$ (Fig. 6b). While, the flocculation activity of strain CPO14 was decreased gradually by increasing the reaction temperature above $50{ }^{\circ} \mathrm{C}$. It is elucidated that flocculation efficiency increments as the clay suspension temperature increased from $5-70{ }^{\circ} \mathrm{C}$, but decreased as the clay suspension temperature increased above $70{ }^{\circ} \mathrm{C}$. This result indicates that the too high clay suspension temperature is unfavorable for the flocculation performance of the biopolymer. This can be explained by chemical kinetics. Both the rate of biopolymer

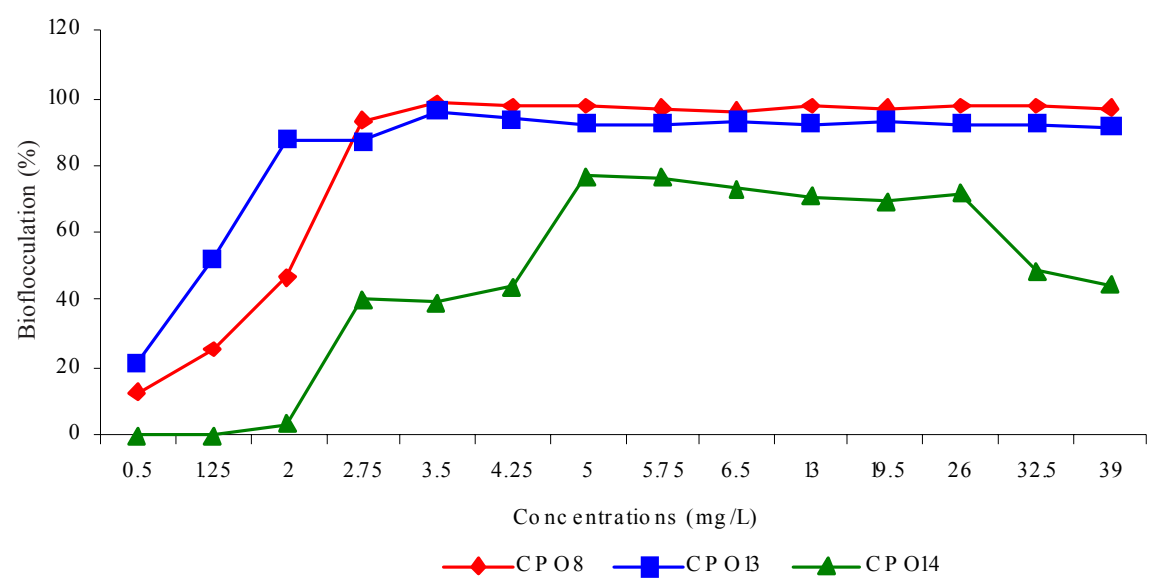

Fig. 5: The effect of dosage on the flocculation activity of the partially purified biopolymers from strains $\mathrm{CPO} 8, \mathrm{CPO} 13$ and $\mathrm{CPO} 14$ 


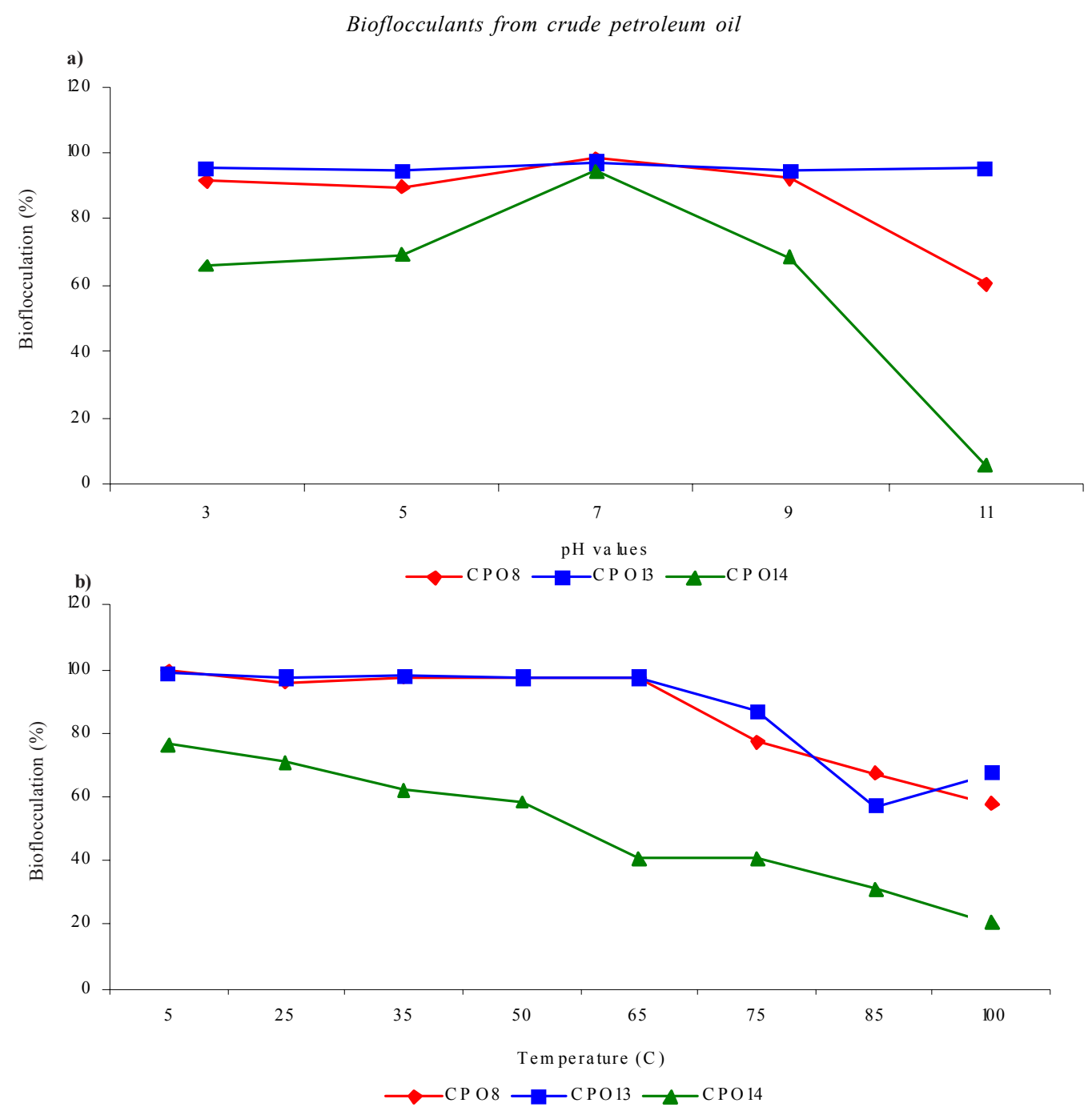

Fig. 6: The influence of initial $\mathrm{pH}$ (a) and temperature (b) of Kaolin clay suspensions on the flocculation activity of the partially purified biopolymers from strains CPO8, CPO13 and CPO14

diffusion and suspended particle collision frequency were improved at higher temperatures, this contributes to the increase in rate of reaction (Lu et al., 2005; Gong et al., 2008). The flocculating activity of strain CPO14 that decreased significantly when the temperature exceeded $50^{\circ} \mathrm{C}$. This can be explained by denaturalization of proteins in the bioflocculant and an increase in hot movement of kaolin particles (Liu et al., 2009).

\section{CONCLUSION}

Three bioflocculant-producing strains were isolated from contaminated crude petroleum oil. Two of them CPO8 and CPO13 are belonging to the genus Bacillus, while strain CPO14 identified as Pseudomonas. Chemical analysis showed that the main compositions of their partially purified bioflocculants were carbohydrates containing some proteins. FTIR indicated the presence of carboxyl, hydroxyl, and methoxyl groups. 1HNMR analysis confirmed that the extracted bioflocculants were glycoproteins. The highest flocculation activities of strains CPO8, CPO13 and CPO14 were $96.03 \%, 92.17 \%$ and $97.59 \%$, respectively at $24 \mathrm{~h}$ of cultivation. The thermal and $\mathrm{pH}$ stabilities of the biopolymer solution indicated its thermal stability over the temperature range of $\left(5-100^{\circ} \mathrm{C}\right)$. Moreover, the biopolymer solution was suitable to be applied in neutral, weakly acid and 
weakly alkaline circumstances. The advantageous properties of these bioflocculants, such as stable thermal and $\mathrm{pH}$ characteristics and dosing rate comparable to those of chemical flocculants to flocculate suspended solids, suggest its potential industrial utility.

\section{ACKNOWLEDGEMENTS}

This work was supported by a grant from the Egyptian Science and Technology Development Fund (STDF) (Grant No. 743). The study was conducted at Environmental Biotechnology Department, Genetic Engineering and biotechnology Institute, City for Scientific Research and Technology Applications, Alexandria, Egypt.

\section{REFERENCES}

Abd-El-Haleem, D.; Al-Thani, R.; Al-Mokemy, T.; Al-Marii, S.; Hassan, F., (2008). Isolation and characterization of extracellular bioflocculants produced by bacteria isolated from Qatari Ecosystems. Pol. J. Microbiol., 57 (3), 231239 (9 pages).

Al-Thani, R.; Abd-El-Haleem, D.; Al-Shammri, M., (2009). Isolation and characterization of polyaromatic hydrocarbons-degrading bacteria from different qatari soils. Afr. J. Microbiol. Res., 3 (11), 761-766 (6 pages).

Besra, L.; Sengupta, D. K.; Roy, S. K.; Ay, P., (2003). Influence of surfactants on flocculation and dewatering of kaolin suspensions by cationic polyacrylamide (PAM-C) flocculant. Sep. Purif. Tech., 30 (3), 251-264 (14 pages).

Bradford, M. M., (1976). A rapid and sensitive method for the quantitation of microgram quantities of protein utilizing the principle of proteindye binding. Analys. Biochem., 72, 248-254 (5 pages).

Chaplin, M. F.; Kennedy, J. F., (1994). Carbohydrate Analysis, seconded. Oxford University Press, New York, pp. 138 141 (4 pages).

Collins, E. A.; Bares, J.; Billmeyer, F. W., (1973). Experiments in Polymer Science. New York: Wiley, pp. 125-130 (6 pages).

De-Beer, T.; van-Zuylen, C. W. E. M.; HaÊ, K.; Boelens, R.; Kaptein, R.; Kamerling, J. P.; Vliegenthart, J. F. G., (1994). Rapid and simple approach for the NMR resonance assignment of the carbohydrate chains of an intact glycoprotein. FEBS Lett., 348 (1), 1-6 (6 pages).

Deng, S. B.; Bai, R. B.; Hu, X. M.; Luo, Q., (2003). Characteristics of a bioflocculant produced by Bacillus mucilaginosus and its use in starch wastewater treatment. Appl. Microbiol. Biotech., 60 (5), 588-593 (6 pages).

Dermlim, W.; Prasertsan, P.; Doelle, H., (1999). Screening and characterization of bioflocculant produced by isolated Klebsiella sp. Appl. Microbiol. Biotech., 52 (5), 698-703 (6 pages).

Divakaran, R.; Sivasankara, V. N., (2001). Flocculation of kaolinite suspensions in water by chitosan. Water Res., 35 (16), 3904-3908 (5 pages).

Faust, S. D.; Aly, O. M., (1983). Removal of particulate matter by coagulation. In Chemistry of Water Treatment, Butterworth Publishers, Boston, pp. 277-367 (91 pages).

Francy, D. S.; Thomas, J. M.; Raymond, R. L.; Ward, C. H., (1991). Emulsification of hydrocarbons by subsurface bacteria. J. Ind. Microbiol., 8 (4), 237-246 (10 pages).

Ganesh Kumar, C.; Joo, H. S.; Choi, J. W.; Koo, Y. M.; Chang, C. S., (2004). Purification and characterization of an extracellular polysaccharide from haloalkalophilic Bacillus sp. I-450. Enzyme Microb. Tech., 34 (7), 673-681 (9 pages)

Gong, W. X.; Wang, S. G.; Sun, X. F.; Liu, X. W.; Yue, Q. Y.; Gao, B. Y., (2008). Bioflocculant production by culture of Serratia ficaria and its application in wastewater treatment. Bioresour. Tech., 99 (11), 4668-4674 (7 pages).

Kim, L. S.; Hong, S. J.; Son, M. K.; Lee, Y. H., (2006). Polymeric and compositional properties of novel extracellular microbial polyglucosamine biopolymer from new strain of Citrobacter sp. BL-4. Biotech. Lett., 28 (4), 241-245. (5 pages)

Kumar, C. G.; Joo, H. S.; Choi, J. W., (2004). Purification and characterization of an extracellular polysaccharide from haloalkalophilic Bacillus sp. I-450[J]. Enzyme Microb. Tech., 34 (7), 673-681 (9 pages).

Kurane, R.; Nohata, Y., (1991). Microbial flocculation of waste liquids and oil emulsions by a bioflocculant from Alcaligenes latus. Agr. Biol. Chem., 55 (4), 1127-1129. (3 pages)

Kurane, R.; Takeda, K.; Suzuki, T., (1986). Screening for characteristics of microbial flocculants. Agr. Biol. Chem., 50, 2301-2307 (7 pages).

Kwon, G. S.; Moon, S. H.; Hong, S. D.; Lee, H. M.; Kim, H. S.; OH, H. M., (1996). A novel flocculant biopolymer produced by Pestalotiopsis sp. KCTC 8637P. Biotech. Lett., 18 (12), 1459-1464 (6 pages).

Lee, S. H.; Lee, S. O.; Jang, K. L.; Lee, T. H., (1995). Microbial flocculant from Arcuadendron sp. TS-49. Biotech. Lett., 17 (1), 95-100 (6 pages).

Liu, W.; Wang, K.; Li, B.; Yuan, H.; Yang, J., (2010). Production and characterization of an intracellular bioflocculant by Chryseobacterium daeguense W6 cultured in low nutrition medium. Biores. Tech., 101 (3), 1044-1048 (5 pages).

Liu, W.; Yuan, H; Yang, J.; Li, B., (2009). Characterization of bioflocculants from biologically aerated filter backwashed sludge and its application in dying wastewater treatment. Biores. Tech., 100 (9), 2629-2632 (4 pages).

Lu, W.; Zhang, T.; Zhang, D.; Li, C.; Wen, J.; Du, L., (2005). A bioflocculant produced by Enterobacter aerogenes and its use in defecating the trona suspension. Biochem. Eng. J., 27 (1), 1-7 (7 pages).

Murray, E.; Doetsch R. N.; Robinow, C. F., (1994). Determinative and cytological light microscopy. In: Gerhardt P, Murray RGE, Wood WA, Krieg NR (eds) Methods for general and molecular bacteriology. American Society for Microbiology, Washington, DC, pp 21-41(21 pages).

Rossini, M.; Garcia, J.; Galluzzo, M., (1999). Optimization of the coagulation-flocculation treatment: influence of rapid mix parameters. Water Res., 33 (8), 1817-1826 (10 pages).

Salehizadeh, H.; Shojaosadati, S. A., (2001). Extracellular biopolymeric flocculants: Recent trends and biotechnological importance. Biotech. Adv., 19 (5), 371-385 (15 pages).

Shih, I. L.; Van, Y. T.; Yeh, L. C., (2001). Production of a biopolymer flocculant from Bacillus licheniformis and its 
flocculation properties. Bioresour. Tech., 78 (3), 267-272 (6 pages).

Stauber, J. L.; Florence, T. M.; Davies, C. M.; Adams, M. S.; Buchanan, S. J., (1999). Bioavailability of Al in alum treated drinking water. J. Am. Water Works Assoc., 91 (11), 84-93 (10 pages).

Takagi, H.; Kadowaki, K., (1985). Flocculant production by Paecilomyces sp.: taxonomic studies and culture condition for production. Agr. Biol. Chem., 49, 3151-3157 (7 pages).

Xia, S. Q.; Zhang, Z. Q.; Wang, X. J.; Yang, A.; Chen, L.; Zhao, J. F.; Leonard, D.; Jaffrezic-Renault, N., (2008). Production and characterization of a bioflocculant by Proteus mirabilis TJ-1. Bioresour. Tech., 99 (14), 6520-6527 (8 pages).

Xiong, Y.; Wang, Y.; Yu, Y.; Li, Q.; Wang, H.; Chen, R.; He, N., (2010). Production and characterization of a novel bioflocculant from Bacillus licheniformis. Appl. Environ. Microbiol., 76 (9), 2778-2782 (5 pages).

Yin, H.; Qiang, J.; Jia, Y.; Ye, J.; Peng, H.; Qin, H.; Zhang, N.; He, B., (2009). Characteristics of biosurfactant produced by
Pseudomonas aeruginosa S6 isolated from oil-containing wastewater. Process Biochem., 44 (3), 302-308 (7 pages).

Yokoi, H.; Natsuda, O.; Hirose, J.; Hayashi, S.; Takasaka, Y., (1995). Characteristics of a biopolymer flocculant produced by Bacillus sp. PY-90. J. Ferment. Bioeng., 79 (4), 378380 (3 pages).

Yokoi, H.; Yoshida, T.; Mori, S.; Hirose, J.; Hayashi, S.; Takasaki, Y., (1997). Biopolymer flocculant produced by an Enterobacter sp. Biotech. Lett., 19 (6), 569-573 (5 pages).

Yong, P.; Bo, S.; Yu, Z., (2009). Research on flocculation property of bioflocculant PG.a21 Ca. Mod. Appl. Sci., 3 (6), 106-112 (7 pages).

Zhang, Z. Q.; Lin, B.; Xia, S. Q.; Wang, X. J.; Yang, A. M., (2007). Production and application of a novel bioflocculant by multiple-microorganism consortia using brewery wastewater as carbon source. J. Environ. Sci. China., 19 (6), $667-673$ ( 7 pages).

\section{AUTHOR (S) BIOSKETCHES}

Zaki, S., Ph.D., Associate Professor, Department of Environmental Biotechnology, Genetic Engineering and Biotechnology Research Institute, City for Scientific Research and Technology Applications, Burgelarab, Alexandria, Egypt, Email: saharzaki@yahoo.com

Farag, S., Ph.D., Assistant Professor, Department of Environmental Biotechnolog, Genetic Engineering and Biotechnology Research Institute, City for Scientific Research and Technology Applications, Burgelarab, Alexandria, Egypt, Email: sohafarag88@yahoo.com

Abu Elreesh, G., Ph.D., Assistant Professor, Environmental Biotechnology Department, Genetic Engineering and Biotechnology Research Institute, City for Scientific Research and Technology Applications, Burgelarab, Alexandria, Egypt.

Email: g_abouelrish@yahoo.com

Elkady, M., Ph.D., Assistant Professor, Department of Fabrication Technology, Advanced Technology and New Materials Research Institute (ATNMRI), Mubarak City for Scientific Research and Technology Applications, Alexandria, Egypt.

Email: maroelkady@yahoo.com

Nosier, M., Ph.D. candidate, Department of Environmental Biotechnology, Genetic Engineering and Biotechnology Research Institute, City for Scientific Research and Technology Applications, Burgelarab City, Alexandria, Egypt. Email: mnosier1987@yahoo.com

Abd El Haleem, D., Ph.D., Professor and Head of the Department of Environmental Biotechnology, Genetic Engineering and Biotechnology Research Institute, City for Scientific Research and Technology Applications, Burgelarab, Alexandria, Egypt.

Email: abdelhaleemm@yahoo.de

How to cite this article: (Harvard style)

Zaki, S.; Farag, S.; Abu Elreesh, G.; Elkady, M.; Nosier, M.; Abd El Haleem, D., (2011). Characterization of bioflocculants produced by bacteria isolated from crude petroleum oil. Int. J. Environ. Sci. Tech., 8 (4), 831-840. 